\title{
Karakter Yuridis Sanksi Hukum Administrasi: Suatu Pendekatan Komparasi
}

\author{
Sri Nur Hari Susanto \\ Fakultas Hukum, Universitas Diponegoro \\ Email : nurhari60@yahoo.co.id
}

\begin{abstract}
The concept of administrative sanctions is a doctrinal idea that is not normatively defined. The purpose of regulating sanctions in administrative law legislation is to counteract the feeling of impunity against certain violations of the rules of public law. Typical administrative law sanctions indicate juridical characters that are not the same, some have reparatoir/herstel characters (bestuursdwang and dwangsom), punitive - condemnatoir / bestraffende characters (administrative fines) and mixed characters (withdrawal of favorable decisions).
\end{abstract}

Keywords: Administrative sanctions, Juridical characters.

\begin{abstract}
Abstrak
Konsep sanksi administrasi merupakan gagasan doctrinal yang tidak didefinisikan secara normatif. Tujuan diaturnya sanksi dalam peraturan perundang-undangan hukum administrasi adalah untuk menangkal perasaan impunitas terhadap pelanggaran tertentu dari peraturan hukum publik. Sanksi hukum administrasi yang khas menunjukkan karakter yuridis yang tidak sama, ada yang memiliki karakter pemulihan/reparatoir (bestuursdwang dan dwangsom), karakter hukuman/condemnatoir (denda administrasi) dan karakter campuran (penarikan keputusan yang menguntungkan).
\end{abstract}

Kata Kunci : Sanksi administrasi, Karakter yuridis.

\section{A. Pendahuluan}

Sanksi merupakan bagian penting dalam peraturan perundang-undangan. Diaturnya sanksi dalam batang tubuh peraturan perundang-undangan dimaksudkan, agar segala ketentuan yang telah dirumuskan (diatur) dapat dilaksanakan secara tertib dan tidak dilanggar. Peraturan perundang-undangan di bidang hukum administrasi senantiasa memberi wewenang kepada badan pemerintahan untuk menegakkan sanksi, manakala terjadi pelanggaran terhadap norma-norma hukum administrasi yang berlaku. Penegakan sanksi hukum administrasi senantiasa berjalan secara paralel dengan penggunaan wewenang pemerintahan yang 
dijalankan oleh badan pemerintahan. Sanksi administrasi dan penegakannya, dengan demikian akan menjadi titik awal dalam implementasi yang dilakukan oleh badan pemerintahan yang acapkali menciptakan hubungan hukum spesifik dengan warga masyarakat dan badan hukum perdata.

Pada umumnya tidak ada gunanya memasukkan kewajiban-kewajiban atau laranganlarangan bagi warga di dalam peraturan perundang-undangan tata usaha negara, manakala aturan-aturan tingkah laku itu tidak dapat dipaksakan oleh tata usaha negara (dalam hal dimaksud diperlukan). ${ }^{1}$ Asas legalitas dalam bidang pemerintahan telah memberikan pemahaman bahwa segala tindak pemerintahan harus didasarkan pada wewenang yang bersumber pada peraturan perundang-undangan.

Menurut Indroharto, ${ }^{2}$ asas tersebut mencanangkan bahwa tanpa adanya dasar wewenang yang diberikan oleh suatu peraturan perundang-undangan yang berlaku, maka segala macam tindakan aparat pemerintah itu tidak akan memiliki wewenang yang dapat mempengaruhi atau mengubah keadaan atau posisi hukum warga masyarakatnya. Hal ini berarti, bahwa setiap wewenang pemerintahan untuk melakukan kebijaksanaan dan tindakan hukum TUN, baik mengenai bentuk tindakan-tindakan hukum demikian itu serta isi hubungan hukum yang diciptakan olehnya, harus ada dasar atau sumbernya pada (diberikan oleh) suatu ketentuan peraturan perundang-undangan (hukum tertulis).

Pengaruh yang dilakukan oleh badan pemerintahan (dengan wewenang publiknya) terhadap warga masyarakat dan/atau badan hukum perdata dalam menjalankan aturan-aturan hukum administrasi, merupakan bentuk konkrit dalam menjalankan fungsi normatif (normatievefunctie/legitimerendefunctie), fungsi instrumental (instrumentelefunctie) dan fungsi jaminan (waarborgfunctie) dari hukum administrasi. Pendekatan fungsi normatif dimaksudkan bahwa hukum administrasi telah memberi dasar hukum bagi badan pemerintahan dalam melakukan tindakan dan/atau mengambil keputusan melalui peraturan pembentukan badan pemerintahan beserta wewenangnya, fungsi instrumental dimaksudkan, bahwa hukum administrasi pertama dan terutama dipandang sebagai sarana untuk mencapai tujuan (doel) tertentu. Hal tersebut penting untuk dipahami bahwa menjalankan fungsi

\footnotetext{
${ }^{1}$ Philipus M Hadjon, Pengantar Hukum Administrasi Indonesia, Cet.ketiga, (Yogyakarta : Gajah Mada University Press, 1994), hlm. 245.

2 Indroharto, Usaha Memahami Undang - Undang Tentang Peradilan Tata Usaha Negara, Buku I: Beberapa Pengertian Dasar Hukum Tata Usaha Negara, (Jakarta : Pustaka Sinar harapan, 1994), hlm. 83.
} 
instrumental berarti menggunakan norma hukum administrasi sebagai alat khusus. Sasaran kebijakan yang ingin dicapai, ditempuh dengan merumuskan keputusan pemerintah dengan karakter normatif. Keputusan tersebut di satu sisi, ditandai dengan tingkat paksaan tertentu dan di sisi lain, harus memenuhi persyaratan hukum dan keadilan. Hukum tidak pernah bisa menjadi sarana netral yang dapat digunakan terlepas dari tujuannya. Fungsi instrumental dalam hukum administrasi menunjukkan bahwa badan-badan pemerintah akan menggunakan wewenang mereka yang sah guna menjaga kepentingan publik. Tugas-tugas pemerintah ini telah berkembang sejak pada abad ke-20 dan menjadikan keterlibatan pemerintah yang sangat luas dan beragam dengan publik. Sedangkan fungsi jaminan, status badan pemerintahan dengan tindakan yang dilakukan adalah untuk menjamin posisi hukum warga negara ketika berhadapan dengan pemerintah. Ini selalu memainkan peran penting dalam mewujudkan bagian umum dari hukum administrasi substantif dan hukum administrasi prosedural. Jaminan yang paling penting bagi warga negara adalah hak dan prosedur umum dan khusus yang ditawarkan oleh hukum administrasi : aturan hukum khusus, yang dilengkapi dengan materi umum dan jaminan formal dari undang-undang dan prinsip-prinsip/asas-asas hukum tidak tertulis dari pemerintahan yang baik.

Hukum administrasi disatu sisi menyediakan sarana-sarana yuridis bagi badan pemerintahan untuk merelisasikan tujuan-tujuan pemerintahan yang dikehendaki, dan di sisi lain menyediakan kepada masyarakat jaminan terhadap tindakan pemerintahan yang tidak tepat dan tidak sah.

Tujuan dicantumkannya (diatur) sanksi dalam peraturan perundang-undangan hukum administrasi adalah untuk menangkal perasaan impunitas (pembiaran) dengan melakukan pelanggaran tertentu dan beberapa perilaku serius (yang bagaimanapun dianggap sebagai gangguan) dan tidak lagi diselesaikan melalui sanksi pidana, tetapi dengan sanksi administrasi.

Penerapan sanksi administrasi dalam suatu hubungan hukum antara pemerintah dan masyarakat merupakan salah satu bentuk dari tindak pemerintahan yang dilakukan dalam rangka penegakan hukum administrasi. Pendekatan konsep tentang penerapan sanksi administrasi dengan demikian tidak bisa dipisahkan dari pembahasan/kajian tentang tindak pemerintahan. Tindak pemerintahan meliputi semua perbuatan yang dilakukan oleh organ 
administrasi dalam rangka menyelenggarakan tugas pemerintahan. Tugas pemerintahan meliputi seluruh kegiatan negara di luar kegiatan pembentukan undang-undang dan peradilan. Hal ini sejajar dengan pengertian "besturen" dalam kepustakaan hukum administrasi di Belanda.

Pemerintahan dalam arti luas (regering) meliputi pembuatan peraturan (regelgeven), pemerintahan dalam arti sempit (besturen), dan mengadili (geschilbeslechting). ${ }^{3}$ Pelaksanaan terhadap sanksi yang diterapkan badan pemerintahan berlaku sebagai suatu keputusan yang memberi beban (belastende beschikking) dan membawa serta hakikat (sifat) dari sanksi. Bagi jenis tindakan pemerintahan terkandung secara khusus adanya asas kecermatan (zorgvuldigheidsbeginsel) dalam rangka asas umum pemerintahan yang layak, artinya harus ditetapkan pada titik-titik mana seorang warga dipandang telah lalai ${ }^{4}$. Warga yang dikenai sanksi senantiasa juga harus diberi kemungkinan untuk mengajukan banding pada hakim (administratif).

Sanksi merupakan salah satu isu sentral dalam hukum administrasi. Sampai sat ini belum ada referensi standar yang dapat dijadikan rujukan tentang apa yang dimaksud dengan sanksi. Berbagai pendapat tentang sanksi banyak disampaikan dalam referensi hukum administrasi, tetapi pendapat-pendapat tersebut belum mencapai pada satu kesepakatan yang diterima secara umum. Logisnya pengertian tentang sanksi (hukum administrasi) diatur secara khusus dalam Undang-Undang Hukum Administrasi Umum. Isu yang diangkat dalam tulisan ini adalah : Bagamaimana konsep sanksi dan konsep sanksi administrasi dalam peraturan perundang-undangan hukum administrasi (mengingat tidak adanya standar rujukan). Dan bagaimana karakter yuridis dari sanksi hukum administrasi.

\section{B. Pembahasan}

\section{Konsep Sanksi dan Konsep Sanksi Administrasi.}

Sanksi dideskripsikan sebagai: "aturan yang menentukan konsekuensi dari ketidakpatuhan atau terhubung dengan pelanggaran norma" (de sanctie wordt gedefinieerd als: "regels die voorschrijven welke gevolgen aan de niet naleving of de

\footnotetext{
${ }^{3}$ E. Utrcht, Pengantar Hukum Administrasi Negara Indonesia, (Surabaya : Pustaka Tinta Mas, 1986), hlm. 13.

${ }^{4}$ Philipus M Hadjon, Op.Cit., hlm 247
} 
overtreding van de normen verbonden worden"). ${ }^{5}$ Sanksi tersebut digunakan sebagai alat kekuasaan yang berusaha untuk memenuhi/mematuhi norma dan usaha tersebut ditujukan untuk meminimalkan kerugian yang disebabkan oleh pelanggaran norma. Literatur hukum Rumania mendefinisikan sanksi sebagai :" the sanction as a consequence of not observing a rule of conduct prescribed or sanctioned by the state. ${ }^{6}$ ( sanksi sebagai konsekuensi dari tidak mematuhi aturan perilaku yang ditentukan atau disetujui oleh negara).

Henry Campbell Black ${ }^{7}$ merumuskan sanksi sebagai "that part of a law which is designed to secure enforcement by imposing a penalty for its violation or offering a reward for its observance". (Bagian dari hukum yang dirancang untuk mengamankan penegakan hukum dengan menjatuhkan hukuman atas pelanggarannya atau menawarkan ganjaran atas ketaatannya). Selanjutnya Bryan A. Garner ${ }^{8}$ menyatakan, sanksi (sanction) adalah: "A penalty or coercive measure that results from failure to comply with a law, rule, or order (a sanction for discovery abuse)" ("Hukuman atau tindakan paksaan yang dihasilkan dari kegagalan untuk mematuhi hukum, aturan, atau perintah (sanksi untuk menemukan/deteksi penyalahgunaan)"

Amnesty International ${ }^{9}$ mendeskripsikan sanksi sebagai berikut :"sancties zijn alle maatregelen, zoals juridische straffen en disciplinaire straffen, waarmee negatief wordt gereageerd op ongewenst gedrag". (Sanksi adalah semua tindakan, seperti sanksi hukum dan disiplin, yang merespons secara negatif terhadap perilaku yang tidak diinginkan).

Menurut Utrecht, yang dimaksud dengan sanksi adalah akibat dari sesuatu perbuatan atau suatu reaksi dari pihak lain, baik itu manusia atau lembaga sosial atas sesuatu perbuatan manusia. ${ }^{10}$

${ }^{5}$ Dupont L., Verstraeten R., Handboek Belgisch Strafrecht, (Leuven : Acco, 1990), hlm. 74-75

${ }^{6}$ Elena Mihaela Fodor, General Principles of Administrative Sanctions in The Romanian Law, Fiat Iustitia Journal, Vol. 1, Issue 1, 2007, hlm 1

${ }^{7}$ Henry Campbell Black, Black's Law Dictionary with Pronounciations, Fifth Edition, (St Paul Minn : West Publishing, 1979), hlm. 1203.

${ }^{8}$ Bryan A. Garner (Editor in Chief)), Black's Law Dictionary, Seventh Edition, (St. Paul Minn : West Group, 1999), hlm.1341

9 Amnesty International, Ontleend aan de Encyclopedie van de Mensenrechten, lihat dalam https://www.ensie.nl/amnesty-international/sancties

${ }^{10}$ Utrecht, Pengantar Dalam Hukum Indonesia, (Jakarta : Penerbit Ichtiar, 1992), hlm. 17. 
Deskripsi di atas apabila dicermati, menunjuk kepada suatu keadaan yang memberikan ruang lingkup tentang sanksi, sehingga dapat dipertimbangkan di sini, bahwa yang dimaksud dengan sanksi adalah alat kekuasaan hukum yang dirancang untuk mengamankan penegakan hukum yang berupa semua tindakan, sebagai reaksi atau respon negatif yang disebabkan oleh ketidakpatuhan atau pelanggaran terhadap norma.

Konsep sanksi administrasi adalah gagasan doktrinal dan tidak didefinisikan secara normatif di dalam undang-undang. Doktrin dalam hukum administrasi menunjukkan banyak definisi yang berbeda dari istilah ini. Ciri umum yang ditekankan oleh sebagian besar penulis adalah keadaan bahwa sanksi administrasi merupakan konsekuensi negatif dari pelanggaran terhadap kewajiban dan tugas yang bersifat administrasi dan legal. Sanksi administrasi adalah salah satu jenis sanksi hukum, yang ditetapkan untuk memastikan penghormatan terhadap ketentuan hukum.

Penerapan sanksi administrasi tidak dapat dilepaskan dari kebijakan secara umum yang bertujuan untuk mewujudkan ketertiban, memberi kepastian hukum dan jaminan perlindungan terhadap hak setiap orang dari suatu gangguan. Penegakan norma hukum administrasi merupakan kewenangan administrasi negara untuk meluruskan terjadinya pelanggaran dengan melakukan suatu tindakan dengan cara memberikan sanksi administrasi.

Sanksi administratif secara luas dipahami sebagai sanksi yang dijatuhkan oleh pembentuk peraturan tanpa intervensi oleh pengadilan atau tribunal (Administrative sanctions are broadly understood as being sanctions imposed by the regulator without intervention by a court or tribunal. $)^{11}$

Public Administration Act Europe Union (UU Uni Eropa tentang Administrasi Publik) merumuskan sanksi administrasi sebagai berikut: "By administrative sanction is meant a negative reaction that may be applied by an administrative agency in response to an actual breach of a statute, regulation or individual decision, and which is deemed

\footnotetext{
${ }^{11}$ J. Dara Lynott, Administrative Sanctions, lihat dalam https://www.slideshare.net/DLynott/administrative-sanctions?from_action=save
} 
to be a criminal sanction pursuant to the European Convention on Human Rights." 12 (Sanksi administratif berarti reaksi negatif yang dapat diterapkan oleh badan administrasi dalam menanggapi pelanggaran undang-undang, peraturan, atau keputusan individual, dan yang dianggap sebagai sanksi hukuman (pidana) sesuai dengan Konvensi Eropa tentang Hak Asasi Manusia).

Yucel Ogurlu ${ }^{13}$ mengemukakan bahwa :" Administrative sanctions, as a sort of administrative acts, are a dimension of the unilateral decision-making power of the Administration. This is the power to decide, to apply and enforce sanctions against individuals who violates laws of public order." (Sanksi administratif, sebagai semacam tindakan administratif, adalah dimensi dari kekuasaan pengambilan keputusan administratif secara sepihak. Ini adalah kekuasaan untuk memutuskan, untuk menerapkan dan menegakkan sanksi terhadap individu yang melanggar hukum ketertiban umum). Sanksi ini selalu dengan karakter hukuman. Penarikan izin terkadang dapat digunakan sebagai sanksi.

Kepustakaan hukum administrasi Belanda, misalnya Willem van Wijk/Konijnenbelt ${ }^{14}$ menyatakan sanksi hukum administrasi sebagai berikut :

${ }^{12}$ lihat Public Administration Act Europe Union, Chapter IX : Administrative sanctions, (Section) 43 (Scope), Act Relating to Procedure in Cases Concerning the Public Administration.

${ }^{13}$ Yucel Ogurlu, Administrative Sanctioning System in Turkey, hlm. 2, lihat dalam http://www.idare.gen.tr/ogurlu-administrative.htm

${ }^{14}$ van Wijk/Konijnenbelt, Hoofdstukken van Administratiefrecht, (Gravenhage : Vuga Uitgeverij’s, 1984), hlm. 281. Pendapat van Wijk/Konijnnenbelt tersebut telah mengalami perkembangan dan disampaikan pada buku yang sama dalam edisi revisi tahun 1988 dan tahun 1995. Pada edisi revisi tahun 1988, pengertian sanksi hukum administrasi dinarasikan sebagai :" De sancties in het administratiefrecht zijn de publiekrechtelijke machtmiddelen die de overheid kan aanwenden als reactie op niet-naleving van verplichtingen die voortvloeien uit administratiefrechtelijke normen" (Sanksi hukum administrasi adalah alat kekuasaan yang bersifat hukum publik yang digunakan oleh penguasa sebagai reaksi dari ketidakpatuhan terhadap kewajiban yang ditentukan dalam norma-norma hukum administrasi. (ada tambahan verplichtingen die voortvloeien = kewajiban yang ditentukan). van Wijk/Konijnenbelt, Hoofdstukken van Administratiefrecht, (Gravenhage : Vuga uitgeverij's, 1988), hlm. 327 Sedangkan dalam edisi tahun 1995, pengertian sanksi hukum administrasi dinarasikan sebagai :" De sancties in het administratiefrecht zijn de door het publiekrecht voorziene, belastende maatregelen die de overheid kan aanwenden als reactie op niet-naleving van verplichtingen die voortvloeien uit administratiefrechtelijke normen". (langkah-langkah memberatkan/membebani yang diatur hukum publik yang digunakan penguasa sebagai reaksi terhadap ketidakpatuhan dari kewajiban yang ditentukan dalam norma-norma hukum administrasi). (ada tambahan de door het publiekrecht voorziene, belastende maatregelen = langkahlangkah memberatkan/membebani yang diatur hukum publik; verplichtingen die voortvloeien = kewajiban yang ditentukan) lihat Wijk/Konijnenbelt, Hoofdstukken van Administratiefrecht, (Gravenhage : Vuga uitgeverij's, 1995), hlm. 493. Bandingkan dengan Ridwan HR, Hukum Administrasi Negara, Edisi Revisi, ( Jakarta : Rajagrafindo Persada, 2011), hlm. 299-300. 
"De sancties in het administratiefrecht zijn de publiekrechtelijke machtmiddelen die de overheid kan aanwenden als reactie op niet naleving van administratief-rechtelijke normen”. (Sanksi hukum administrasi adalah alat kekuasaan yang bersifat hukum publik yang digunakan oleh penguasa sebagai reaksi dari ketidakpatuhan terhadap normanorma hukum administrasi).

Unsur-unsur dari sanksi hukum administrasi berdasarkan pendapat van Wijk/Konijnenbelt di atas, apabila diurai terdiri dari : Alat kekuasaaan (machtmiddelen); Bersifat hukum publik (publiekrechtelijke); Badan pemerintahan/penguasa (overheid); Reaksi terhadap ketidakpatuhan (reactie op niet naleving); Norma-norma hukum administrasi (administratiefrechtelijke normen). J.J Oostenbrink $^{15}$ mengemukanan juga bahwa sanksi administrasi adalah :"Administratief sancties zijn dus sancties, die voortspruiten uit de relatie overheid-onderdaan en die zonder tussenkomst van derden en met name zonder rechtelijke machtiging rechtstreeks door de administratie zelf kunnen worden opgelegd" (sanksi administrasi adalah sanksi yang muncul dari hubungan antara pemerintah dan warga negara / subyek dan yang dilaksanakan tanpa perantaraan pihak ketiga, yaitu tanpa perantaraan kekuasaan peradilan, tetapi dapat secara langsung dilaksanakan oleh administrasi sendiri).

Selanjutnya J.R. Stellinga ${ }^{16}$ mengemukan bahwa :" De administratieve sanctie een maatregel is, welke genomen wordt, wanneer de burger een publiekrechtelijke regel overtreedt. Daarbij komt dan, dat de sanctie wordt toegepast door een bestuursorgaan, en dat zij bestaat in het toebrengen van een nadeel aan de overtreder. Zulk een nadeel kan bestaan in een geldboete, in het intrekken van een eerder verleende vergunning e.d (sanksi administratif adalah suatu tindakan yang diambil jika warga negara melanggar aturan hukum publik. Selain itu, sanksi diterapkan oleh badan administratif dan menimbulkan kerugian pada pelaku. Kerugian seperti itu dapat berupa denda, dalam penarikan izin yang sebelumnya diberikan dan sejenisnya)

\footnotetext{
${ }^{15}$ J.J Oostenbrink, Administratief Sancties, (Denhaag : Vuga Boekerij, 1967), hlm. 8

${ }^{16}$ J.R. Stellinga, De Administratieve Sancties in Nederland, hlm.354, lihat dalam http://www.aca-europe.eu/colloquia/1972/netherlands-2_nl.pdf
} 
Berdasarkan pandangan-pandangan di muka, sanksi administrasi sebagai reaksi yang dilakukan oleh badan administrasi, merupakan dimensi dari kekuasaan pengambilan keputusan administrasi secara sepihak. Kekuasaan ini adalah kekuasaan untuk memutuskan, menerapkan dan menegakkan sanksi terhadap individu yang melanggar norma hukum administrasi (ketertiban umum).

Hal ini sejalan pula dengan apa yang disampaikan oleh Dupont L. \& Verstraeten $\mathrm{R}$ sebagaimana disitir oleh Liesbet Deben ${ }^{17}$ yang mengatakan "de sanctie wordt gedefinieerd als: 'regels die voorschrijven welke gevolgen aan de niet naleving of de overtreding van de normen verbonden worden' (Sanksi didefinisikan sebagai: "aturan yang menentukan konsekuensi dari ketidakpatuhan atau terhubung dengan pelanggaran norma').

Tujuan penerapan sanksi administrasi terhadap suatu pelanggaran yang terjadi dimak-sudkan sebagai upaya badan administrasi untuk mempertahankan norma-norma hukum administrasi yang telah ditetapkan dalam wujud peraturan perundang-undangan. Memperta-hankan norma hukum administrasi pada dasarnya menjadi konsekuensi logis dari wewenang yang diberikan oleh peraturan perundang-undangan kepada badan pemerintahan untuk :

a) menjamin penegakan norma hukum administrasi;

b) sebagai pelaksanaan dari wewenang pemerintahan yang berasal dari aturan hukum administrasi itu sendiri; dan

c) tanpa melalui perantaraan pihak ketiga (peradilan).

Sanksi hukum administrasi apabila dilihat dari karakter normanya bukan merupakan suatu kewajiban (plicht), tetapi merupakan kewenangan bebas (vrijebevoegdheid) yang mandiri, tidak tergantung pada organ lainnya. ${ }^{18}$ Badan dan/atau pejabat pemerintahan dengan demikian diberi wewenang secara eksklusif untuk menegakkan norma hukum administrasi tanpa bergantung pada institusi lain seperti pengadilan.

\footnotetext{
${ }^{17}$ Liesbet Deben, De positie van de Bestuurlijke Boete, Onderzoekslijn handhaving en beleid, 2004, hlm. 23. Lihat lebih jauh dalam http://www.steunpuntverkeersveiligheid.be/sites/default/files/RA-2004-41.pdf ; lihat juga Dupont L., Verstraeten R., Handboek Belgisch Strafrecht, (Leuven : Acco, 1990), hlm. 74-75

${ }^{18}$ W. Riawan Tjandra, Hukum Administrasi Negara, (Yogyakarta : Sinar Grafika, 2018), hlm. 218.
} 
Kewenangan bebas (vrijebevoegdheid) merupakan bentuk dari kebebasan pemerintahan (vrij bestuur). Menurut N.M Spelt \& J.B.J.M ten Berge sebagaimana disitir oleh Philipus M Hadjon ${ }^{19}$ membedakan 2 (dua) macam kebebasan pemerintahan (vrij bestuur) dalam uraiannya sebagai berikut :

"de vrij die een wettelijke regeling aan een bestuursorgaan kan laten bij het geven van een beschikking wordt wel onderscheiden in "beleidsvrijheid" en beoordelingsvrijheid" (kebebasan yang diizinkan peraturan perundang-undangan bagi organ pemerintahan untuk membuat keputusan dapat dibedakan dalam "kebebasan kebijaksanaan dan kebebasan penilaian").

N.M Spelt \& J.B.J.M ten Berge ${ }^{20}$ menyatakan :"Er is beleidsvrijheid (ook wel discretionaire bevoegdheid in ingezin) indien een wettelijke regeling een bestuursorgaan een bepaalde bevoegdheid verleent, terwijl het aan het organ vrij staat van hhet gebruik van die bevoegdheid af te zien, ook al zijn de voorwaarden voor rechtmatige uitoefening daarvan vervuld" (ada kebebasan kebijaksanaan - wewenang diskresi dalam arti sempit- bila peraturan perundang-undangan memberikan wewenang tertentu kepada organ pemerintahan, sedangkan organ tersebut bebas untuk (tidak) menggunakannya meskipun syarat-syarat bagi penggunaannya secara sah dipenuhi). Selanjutnya kebebasan penilaian dinyatakan sebagai berikut :"Beoordelingsvrijheid (ook wel discretionaire bevoegdheid in oneigenlijkezin) bestaat voorzover het rechtens aan het bestuursorgaan is overgelaten om zelfstanding en exclusief te beoordelen of de voorwaarden voor een rechtmatige uitoefening van een bevoegdheid zijn vervuld" (kebebasan penilaian - wewenang diskresi dalam arti yang tidak sesunguhnya - ada, sejauh menurut hukum diserahkan kepada organ pemerintahan untuk menilai secara mandiri dan eksklusif apakah syarat-syarat bagi pelaksanaan suatu wewenang secara sah telah dipenuhi).

${ }^{19}$ Philipus M Hadjon, Pemerintahan Menurut Hukum (wet en rechtmatig bestuur), Makalah - Bahan Penataran Hukum Administrasi, Kerjasama Utrecht Universitiet dan Universitas Airlangga, 1992, hlm. 3. Lihat juga Philipus M Hadjon, Pemerintahan menurut hukum (Wet-en Rechtmatig Bestuur), dalam Jurnal Yuridika, Surabaya, 1992, hlm. 6-7

${ }^{20}$ N.M Spelt \& J.B.J.M ten Berge, Inleiding Vergunningenrecht, onderzoeksdocument, Utrecht, December 1991. 


\section{Karakter Yuridis Sanksi Hukum Administrasi}

\section{a. Kriteria Organik.}

Apabila sanksi memiliki manfaat yang terkait dengan kepatuhan terhadap norma perilaku, maka hal tersebut merupakan sanksi yang positif. Secara a contrario, maka dalam hubungannya dengan sanksi negatif adalah jika ada perilaku yang menimbulkan kerugian karena melanggar norma (als sancties voordelen verbinden aan de naleving van een gedragsnorm, zijn het 'positieve sancties'. 'Negatieve sancties' verbinden nadelen aan normschendend gedrag) ${ }^{21}$.

Kriteria organik dari karakter sanksi administrasi merupakan satu-satunya cara yang praktis untuk membedakan sanksi administrasi dari jenis sanksi lain, terutama dari sanksi pidana. Oleh karena itu, ruang lingkup sanksi administrasi tidak termasuk ruang lingkup sanksi yang dijatuhkan oleh hakim (hakim pidana, hakim perdata maupun hakim administrasi/PTUN).

Kriteria organik dari karakter sanksi administrasi tersebut melingkupi hal-hal sebagai berikut :

a). Sanksi administrasi menganggap bahwa suatu perbuatan yang menimbulkan gangguan terhadap tatanan norma hukum administrasi, sebagai suatu pelanggaran;

b) Gangguan yang timbul akibat pelanggaran terhadap tatanan norma hukum administrasi, segera dapat dilakukan tindakan oleh badan administrasi;

c). Tindakan yang dilakukan Badan administrasi dalam rangka mengakhiri gangguan terhadap tatanan norma hukum administrasi, dapat berupa tindakan pemulihan (reparatoir - herstel ) dan/atau tindakan penghukuman (condemnatoir - straf).

Pembahasan/kajian terhadap fungsi sanksi hukum, khususnya sanksi administrasi, berhubung dalam ilmu hukum tidak ada konsensus mengenai klasifikasi fungsi-fungsi tertentu dari sanksi hukum (administrasi), maka kita hanya dapat membedakannya melalui cara sebagai berikut :

a) fungsi represif, yaitu fungsi yang memiliki tujuan untuk menimbulkan efek penderitaaan sebagai imbalan atas perilaku yang menyimpang;

21 Johan Put, Administratieve sancties in het Socialezekerheidsrecht, Preventieve rechtsbescherming bij en rechterlijke controle op het opleggen van administratieve sancties in de sociale zekerheid, Jura Falconis Journal, jg 35, 1998-1999, No. 3, hlm. 455-494. Lihat lebih jauh dalam https://www.law.kuleuven.be/apps/jura/artikels/show/87 
b) fungsi preventif, yaitu fungsi yang memiliki tujuan untuk mencegah terjadinya pelanggaran hukum; dan

c). fungsi restitusi/reparasi, yaitu fungsi yang memiliki tujuan untuk memperbaiki kerusakan dan memulihkannya ke dalam keadaan semula seperti tidak adanya pelanggaran (gangguan).

Philipus M. Hadjon ${ }^{22}$ et. al., telah membuat suatu perbedaan antara sanksi administrasi dengan sanksi pidana, yang dapat diragakan sebagai berikut :

\begin{tabular}{|c|c|c|}
\hline Faktor Pembeda & Sanksi Administrasi & Sanksi Pidana \\
\hline SASARAN/TUJUAN & Perbuatan & Pelaku \\
\hline SIFAT & Reparatoir & Condemnatoir \\
\hline$\overline{\text { PROSEDUR }}$ & $\begin{array}{lll}\text { Tanpa harus } & \text { melalui } & \text { prosedur } \\
\text { Peradilan } & & \\
\end{array}$ & Melalui Proses Peradilan \\
\hline
\end{tabular}

Ragaan diatas dapat diterangkan sebagai berikut, bahwa sanksi administrasi ditujukan kepada perbuatan pelanggarannya, agar perbuatan pelanggar itu dihentikan. Sifat sanksi "reparatoir" artinya memulihkan kepada keadaan semula. Sedangkan sanksi pidana ditujukan kepada pelanggar dengan memberi hukuman berupa nestapa. Sifat sanksi "condemnatoir" (straf $=$ menghukum). Prosedur dalam penegakan hukumnya pada sanksi administrasi tanpa harus melalui proses peradilan (non contentious), artinya badan administrasi dengan wewenang publiknya melakukan tindakan penegakan, sedangkan pada sanksi pidana prosedur penegakannya melalui proses peradilan (contentious).

\section{b. Sanksi Pemulihan (Reparatoir/Restorasi) dan Sanksi Hukuman (Condemnatoir).}

Kepustakaan hukum administrasi senantiasa menerangkan jenis-jenis sanksi hukum administrasi yang khas (di samping yang khas masih terdapat jenis sanksi hukum administrasi lainnya seperti sanksi disiplin misalnya), meliputi :

1) Paksaan pemerintahan (bestuursdwang);

2) Pembayaran penalti / uang paksa (dwangsom);

3) Denda administrasi (administratieve/bestuurslijke boete); dan

\footnotetext{
${ }^{22}$ Philipus M Hadjon, et.al, Pengantar Hukum Administrasi Indonesia, (Yogyakarta : Gajah Mada University Press,
} 1994), hlm. 247. 
4) Penarikan keputusan yang menguntungkan (het intrekken van een begunstigende beschikking/withdraw license).

Bertolak dari keempat sanksi hukum administrasi yang khas diatas, maka perlu dilakukan analisis guna mengetahui termasuk ke dalam kategori manakah diantara keempat sanksi tersebut sebagai sanksi pemulihan (reparatoir/restorasi) dan sanksi hukuman (condemnatoir).

Studi komparasi dengan hukum administrasi di Belanda, acapkali menyebut sanksi pemulihan (reparatoir) ini dengan istilah "herstelsancties" dan sanksi hukuman (condemnatoir) dengan istilah "bestraffendesancties". Herstelsancties dimaksudkan untuk menghentikan pelanggaran dan mencegah pelanggaran baru, sedangkan bestraffendesancties dimaksudkan untuk menghukum (memberi hukuman) dan memberi efek jera.

Ketentuan Pasal (Artikel) 5:21 dan Artikel 5:31d AWB ${ }^{23}$ (Algemene Wet Bestuursrecht - UU Hukum Administrasi Umum yang merupakan Kodifikasi Hukum Administrasi di Belanda) menerangkan bahwa perintah yang dikenakan terhadap paksaaan administrasi (bestuursdwang) dan perintah pembayaran penalti/uang paksa (dwangsom) hakikatnya menyangkut sanksi pemulihan (herstelsanties reparatoir/restorasi), di mana tidak ada karakter hukuman (bestraffend), walaupun sanksi ini tidak boleh diremehkan. Bestuursdwang dan dwangsom dengan demikian keduanya memiliki karakter sebagai herstelsancties (sanksi reparatoir / pemulihan).

Sanksi hukum administrasi lainnya yang khas seperti pengenaan denda administrasi (bestuurslijke boete), masih menurut AWB - berdasarkan ketentuan Artikel (pasal) 5:40 dinyatakan bahwa "denda administratif berarti : sanksi hukuman, yang

\footnotetext{
${ }^{23}$ Selengkapnya artikel 5:21 AwB merumuskan sebagai berikut : "Onder last onder bestuursdwang wordt verstaan: de herstelsanctie, inhoudende: a. een last tot geheel of gedeeltelijk herstel van de overtreding, en $b$. de bevoegdheid van het bestuursorgaan om de last door feitelijk handelen ten uitvoer te leggen, indien de last niet of niet tijdig wordt uitgevoerd". (Yang dimaksud di bawah paksaaan administrasi dipahami sebagai: sanksi pemulihan, termasuk: a. perintah untuk sepenuhnya atau sebagian memperbaiki pelanggaran, dan $b$. wewenang badan administratif untuk mengeksekusi perintah melalui tindakan aktual jika perintah tidak dieksekusi atau tidak dilakukan tepat waktu). Selanjutnya artikel (pasal) 5:31d merumuskan :"Onder last onder dwangsom wordt verstaan: de herstelsanctie, inhoudende: a. een last tot geheel of gedeeltelijk herstel van de overtreding, en $b$. de verplichting tot betaling van een geldsom indien de last niet of niet tijdig wordt uitgevoerd. (Yang dimaksud dibawah pengenaan penalti/uang paksa dipahami sebagai : sanksi reparasi, yang meliputi: a. perintah untuk sepenuhnya atau sebagian memperbaiki pelanggaran, dan b. kewajiban untuk membayar sejumlah uang jika perintah tidak dieksekusi atau tidak dilaksanakan tepat waktu).
} 
mencakup kewajiban tanpa syarat untuk membayar sejumlah uang." ${ }^{24}$ Karakter denda administrasi (bestuurslijke boete) dengan demikian menurut AWB merupakan sanksi hukuman (bestraffendesancties) dan tidak ditujukan untuk mengadakan pemulihan keadaan hukum seperti semula (yang sah). Sebelum badan administratif dapat menjatuhkan hukuman ini, sanksi ini harus memenuhi sejumlah besar jaminan. Denda administrasi (bestuurslijke boete) harus ada dasar hukum dalam undang-undang khusus. Ini merupakan amanat dari Pasal $5: 4$ AWB, yang menetapkan prinsip legalitas. Undangundang yang mendasari denda juga harus dapat dikenali dan dirumuskan dengan jelas dan benar. Selain itu hukum harus dapat diprediksi, dalam arti bahwa seorang warga negara dapat segera melihat konsekuensi dari pelanggarannya.

Hukum Administrasi Belanda menerangkan bahwa, denda administrasi merupakan sanksi hukuman yang paling berat dalam hukum administrasi. Oleh karena itu sebelum badan administrasi menjatuhkan hukuman ini, sanksi ini harus memenuhi sejumlah jaminan yang besar (de bestuurlijke boete de meest opgelegde bestraffende sanctie uit het bestuursrecht. Voordat een bestuursorgaan deze straf kan opleggen, moet deze sanctie aan een groot aantal waarborgen voldoen $)^{25}$.

Penarikan kembali keputusan yang menguntungkan (het intrekken van een begunstigende beschikking / withdraw license), merupakan suatu bentuk sanksi campuran antara herstel sancties (sanksi pemulihan/reparatoir) dan bestraffende sancties (sanksi hukuman/ condemnatoir). Hal penarikan kembali keputusan yang menguntungkan (izin misalnya), dapat dilakukan melalui 2 (dua) bentuk, yaitu pembatalan (de opzegging) dan pengembalian (de terugneming). Suatu penarikan keputusan dalam arti pembatalan bisa terjadi, karena badan administrasi ketika mengeluarkan keputusan (izin) berada dalam keadaan dibawah tekanan/paksaan (dwang), curang (bedrog), salah kira (dwaling), sehingga keputusan tersebut mengalami cacat hukum. Pembatalan izin yang demikian

${ }^{24}$ Selengkapnya artikel 5:40 AWB merumuskan sebagai berikut : 1. Onder bestuurlijke boete wordt verstaan : de bestraffende sanctie, inhoudende een onvoorwaardelijke verplichting tot betaling van een geldsom. (Yang dimaksud denda administrasi dipahami sebagai : sanksi hukuman, yang mencakup kewajiban tanpa syarat untuk membayar sejumlah uang). 2. Deze titel is niet van toepassing op de intrekking of wijziging van een aanspraak op financiële middelen. (Klaim ini tidak berlaku untuk penarikan atau perubahan klaim terhadap sumber daya keuangan).

${ }^{25}$ Bestraffende sancties in het bestuursrecht, https://wetenschap.infonu.nl/recht-en-wet/64780-bestraffende-sanctiesin-het-bestuursrecht.html 
merupakan bentuk sanksi hukuman. Bentuk lain dari pembatalan izin bisa disebabkan pemegang izin melanggar larangan-larangan yang diwajibkan di dalam izin. Norma hukum dilanggar ketika izin dilaksanakan dan penarikan ditujukan untuk menambah penderitaan bagi pelaku, sehingga harus ada dasar hukum untuk norma hukum yang dilanggar dan celaan kepada pelaku untuk dasar ini. Sedangkan penarikan kembali keputusan dalam arti pengembalian, karena badan administrasi ketika mengeluarkan keputusan, informasi (data) yang diberikan oleh pemohon kepada badan administrasi tidak benar. Keputusan demikian dianggap tidak pernah ada dan dengan penarikan izin yang diberikan secara tidak sah, maka situasi ilegal dipulihkan (reparatoir/herstel).

Karakter yuridis sanksi hukum administrasi yang khas (paksaan pemerintahan, penalty/uang paksa, denda administrasi dan penarikan keputusan yang menguntungkan) sebagaimana diurai diatas, setelah dilakukan analisis melalui studi komparasi secara normatif dengan hukum administrasi Belanda khususnya dengan AWB (Algemene wet Bestuursrecht), maka dapat diragakan sebagai berikut :

\section{Tabel. Karakter Yuridis Jenis Sanksi}

\begin{tabular}{|lccc|}
\multicolumn{1}{c}{ Jenis Sanksi } & $\begin{array}{c}\text { Karakter Yuridis } \\
\text { Sanksi Pemulihan } \\
\text { (Herstel Sancties } \\
\text { Reparatoir }\end{array}$ & $\begin{array}{c}\text { Sanksi Hukuman } \\
\text { (Bestraffende Sancties / } \\
\text { Condemnatoir }\end{array}$ & $\begin{array}{l}\text { Sanksi } \\
\text { (Herstel \& Bestraf-fende } \\
\text { Sancties) }\end{array}$ \\
\hline $\begin{array}{l}\text { Paksaaan } \\
\text { Pemerintahan }\end{array}$ & $\sqrt{ }$ & - \\
\hline $\begin{array}{l}\text { Penalti/Uang Paksa } \\
\text { Denda Administrasi }\end{array}$ & $\sqrt{ }$ & - & - \\
\hline $\begin{array}{l}\text { Penarikan kembali } \\
\text { Keputusan yang me- } \\
\text { nguntungkan }\end{array}$ & - & $\sqrt{ }$ & - \\
\hline
\end{tabular}

Ragaan di atas jika diperbandingkan dengan pendapat Philipus M Hadjon tentang sifat (karakter) sanksi hukum administrasi yang khas, maka dapat dikatakan bahwa karakter sanksi hukum administrasi tidak hanya memiliki karakter yang pemulihan (reparatoir /herstel) saja, tetapi juga sanksi hukuman (condemnatoir / bestraffende), dan campuran antara pemulihan (reparatoir / herstel) dan hukuman (condemnatoir / bestraffende). 


\section{Simpulan}

Berdasarkan uraian paparan di atas, maka dapat disampaikan pokok simpulan sebagai berikut : Pertama, Sanksi administrasi merupakan instrumen pemaksa yang ditujukan untuk memper-tahankan norma-norma hukum administrasi dan sebagai reaksi terhadap segala bentuk pelanggaran dan/atau ketidakpatuhan yang dilakukan oleh warga negara dan badan privat, agar mentaati norma-norma hukum administrasi yang telah ditetapkan. Kedua, Karakter yuridis sanksi hukum administrasi yang khas bisa dibedakan menjadi karakter pemulihan (reparatoir/herstel), karakter hukuman (condemnatoir/bestraffende), mau-pun karakter campuran (reparatoir dan condemnatoir / herstel dan bestraffende).

Dengan demikian maka adapun saran yang dapat disampaikan adalah pertama, Perlu dilakukan studi mendalam lebih lanjut menyangkut sanksi hukum administrasi dan tidak hanya terbatas pada jenis sanksi hukum administrasi yang khas saja, tetapi juga terhadap jenis sanksi hukum administrasi lainnya. Kedua, Ke depan perlu dibangun dan dikembangkan konsep sanksi hukum administrasi khas Indonesia berdasarkan prinsipprinsip hukum administrasi yang berlaku di Indonesia, dan mengadakan komparasi dengan negara-negara lain sebagai bahan pembanding.

\section{Daftar Pustaka}

Algemene Wet Bestuursrecht (AWB).

Amnesty International, Ontleend aan de Encyclopedie van de Mensenrechten, lihat dalam

Bestraffende sancties in het bestuursrecht, https://wetenschap.infonu.nl/recht-enwet/64780-bestraffende-sancties-in-het-bestuursrecht.html

Black, Henry Campbell, 1979, Black's Law Dictionary with Pronounciations, Fifth Edition, (St West Publishing, St. Paul Minn.

Dupont L., Verstraeten R., 1990, Handboek Belgisch Strafrecht, Acco, Leuven.

E. Utrecht, 1986, Pengantar Hukum Administrasi Negara Indonesia, Pustaka Tinta Mas, Surabaya

E. Utrecht, 1992, Pengantar Dalam Hukum Indonesia, Penerbit Ichtiar, Jakarta.

Elena Mihaela Fodor, General Principles of Administrative Sanctions in The Romanian Law, 2007, Fiat Iustitia Journal, Vol. 1, Issue 1. 
Garner, Bryan A. (Editor in Chief)), 1999, Black's Law Dictionary, Seventh Edition, West Group, St. Paul Minn.

Indroharto, 1994, Usaha Memahami Undang - Undang Tentang Peradilan Tata Usaha Negara, Buku I: Beberapa Pengertian Dasar Hukum Tata Usaha Negara, Pustaka Sinar harapan, Jakarta.

J. Dara Lynott, Administrative Sanctions, lihat dalam

J.J Oostenbrink, 1967, Administratief Sancties, Vuga Boekerij, Denhaag.

J.R. Stellinga, De Administratieve Sancties in Nederland, hlm.354, lihat dalam

Johan Put, Administratieve sancties in het Socialezekerheidsrecht, Preventieve rechtsbescherming bij en rechterlijke controle op het opleggen van administratieve sancties in de sociale zekerheid, Jura Falconis Journal , jg 35, 1998-1999, No. 3, hlm. 455-494. Lihat lebih jauh dalam https://www.law.kuleuven.be/apps/jura/artikels/show/87

Liesbet Deben, De positie van de Bestuurlijke Boete, Onderzoekslijn handhaving en beleid, 2004, Lihat dalam http://www.steunpuntverkeersveiligheid.be/sites/default/files/RA-2004-41.pdf

N.M Spelt \& J.B.J.M ten Berge, 1991, Inleiding Vergunningenrecht, onderzoeksdocument, Utrecht

Philipus M Hadjon, 1992, Pemerintahan menurut hukum (Wet-en Rechtmatig Bestuur), dalam Jurnal Yuridika, Surabaya.

Philipus M Hadjon,et al, 1994, Pengantar Hukum Administrasi Indonesia, Cet.ketiga,: Gajah Mada University Press, Yogyakarta.

Ridwan HR, 2011, Hukum Administrasi Negara, Edisi Revisi, Rajagrafindo Persada, Jakarta.

van Wijk/Konijnenbelt, 1984, Hoofdstukken van Administratiefrecht, Vuga Uitgeverij's, Gravenhage.

W. Riawan Tjandra, 2018, Hukum Administrasi Negara, Sinar Grafika, Yogyakarta.

Yucel Ogurlu, Administrative Sanctioning System in Turkey, lihat dalam 